Journal of Engineering and Applied Sciences 15 (2): 341-349, 2020

ISSN: 1816-949X

(C) Medwell Journals, 2020

\title{
Determining Biopore Infiltration Hole as Catchment Flood in Inundation Area Eastern of Makassar City Based on Geographic Information System (GIS)
}

\author{
Abdul Rivai Suleman, Hamzah Yusuf, Abdul Nabi, Andi Erdiansa, Shanty Halim and Nur Aulia \\ Department of Civil Engineering, State Polytechnic of Ujung Pandang, \\ Jl. Perintis Kemerdekaan Makassar, 90245 South Sulawesi, Indonesia
}

\begin{abstract}
The study aims to determine the suitable location of biopore infiltration holes by utilizing Geographic Information Systems Software (GIS) in adopting appropriate technologies Biopore Infiltration Hole (LRB) at inundation areas in the eastern city of Makassar. The analysis of this study is conducted in the form of qualitative analysis which to identify the type of soil in the research and as well as quantitative analysis to determine the suitable location applied in Biopore Infiltration Hole (LRB). In the outline, the concept of applying the analysis technique of super-impose with the three variables of determining analysis location of Biopore Infiltration Hole (LRB) such as soil type, rainfall and built coefficient region. The results of this study indicate that the three sites are suitable to be applied Biopore Infiltration Hole (LRB), namely; location IV (RT 3 RW 6 Berua), location V (RW 7 Mangga Tiga) and the location VI (RW 16 Blok Ae BTP) in Paccerakkang village which each location requires a number of absorption biopore holes as much as 84,417 for IV location, 6,894-6,644 locations V and VI for the location.The utilization of GIS Software in implementing Biopore Infiltration Hole (LRB) obtained a map view location which is suitable to be applied for biopore hole absorptions and the number of needs in the region.
\end{abstract}

$\underline{\text { Key words: Biopore infiltration hole, catchment flood, inundation areas, Makassar city, GIS, implementing }}$

\section{INTRODUCTION}

Flooding is one of the natural disasters that frequently hit several countries including Indonesia. The excessive waterlogging flood occurs frequently during the rainy season. Puddles arose because of the increased volume of water flowing over the surface of the land, whether as a result of high rainfall or overflow of river water, Indrianawati (2013). Similar to the major city in Indonesia including Makassar.

Makassar city is one of the largest cities in eastern Indonesia which often become flooded every year. In geographic, Makassar city is located in the West coast of South Sulawesi at coordinates $119^{\circ} 18^{\prime} 27.97^{\prime \prime}$ $119^{\circ} 32^{\prime} 31.03^{\prime \prime}$ East longitude and 500'30.18”5¹4'6.49. South latitude with an area about $175.77 \mathrm{~km}^{2}$. Flooding usually occurs from December to February when the highest rainfall annually. Some of the major floods had been occurred in the city of Makassar, namely in 1999, 2000 and 2013. Many factors can influence the occurrence of flooding such as the amount of rainfall intensity. City system is not good, the influence of tidal and global warming as well as the habits of people in throwing garbage into the drainage channel or river.

Urban growth increases every year, caused by changing in land use. One of consequences is increasing surface runoff and decreasing the quantity of water that seep into the soil, caused by flooding during the rainy season and drought in the dry season. During this time, the concept of drainage which widely applied in the cities is the drainage system setting area. This principle concept states that all rainwaters fall in a region must be thrown into the river. Philosophy throwing water puddle river stream could be caused by accepting loads beyond its capacity while not much water can be seeped into the ground (Wahyuningtyas, 2011).

According to Basuki (2013), some water infiltration technology into hearts ground pool for example infiltration basin, infiltration trenches and french drain have been already popular in the society. However, the infiltration of water technology has not been applied widely caused by any different reasons such as need a place to lie between size, time consuming and relatively expensive cost. It is necessary for impregnation technology alternatives that do not require a long processing time also the cheaper cost and environmentally appropriate technology which is appropriate to use water Biopore Infiltration Hole method (LRB).

Biopore Infiltration Hole (LRB) is holes in the ground formed by the activity of organisms in it such as worms, rooting soil, termites and another soil fauna. With the activity of soil fauna in absorption holes, then biopore will be able to absorb water and continue to maintain its existence. It is triggered by Kamir R. Bratan professor of Soil Science and Land Resources Institut Pertanian Bogor, West Java, since, 2000 who invented a method very simple technology but it has an enormous impact on the environment.

Corresponding Author: Abdul Rivai Suleman, Department of Civil Engineering, State Polytechnic of Ujung Pandang, Jl. Perintis Kemerdekaan Makassar, 90245 South Sulawesi, Indonesia 
The method above is technology absorption Biopore Infiltration Hole (LRB). Absorption biopore infiltration holes newly created and filled garbage can enter the water as much as 1.5-1.6 $\mathrm{L} \mathrm{min}^{-1}$ (Rizki, 2014). This research aims to determine:

- Suitable location to be applied biopore infiltration hole

- Utilizing Geographic Information System Software (GIS) in adopting appropriate technology Biopore Infiltration Hole (LRB)

Objectives to be achieved in this study as follows:

- To determine the suitable location applied by biopore infiltration hole

- To take advantage of Geographic Information Systems (GIS) Software in adopting appropriate technologies Biopore Infiltration Hole (LRB) in inundation areas in the eastern city of Makassar

Based on the above issues, it takes a special research to determine the location and the number of Biopore
Infiltration Holes (LRB) as catchment flood in the eastern city of Makassar-based on Geographic Information System (GIS).

\section{MATERIALS AND METHODS}

Location of the study is in the eastern region of Makassar on Tamalanrea village, sub-district and urban village Tamalanrea, Paccerakkang, Biringkanaya District by determining location randomly at three locations in each village as shown in Fig. 1.

Data will be used in this research including primary data and secondary data. Secondary data is obtained by documentation of the agency or agencies associated with this research. The secondary data is used as follows:

- Inundation area data are obtained by Regional Disaster Management Agencies (RDMA) Makassar city

- Topografy map of Makassar city

- Rainfall data are obtained by Meteorology, Cimatology and Geophysics Agencies (MCGA) and Regional Agencies of Pompengan Jeneberang river

- Building density data are obtained by spatial plan service Makassar city

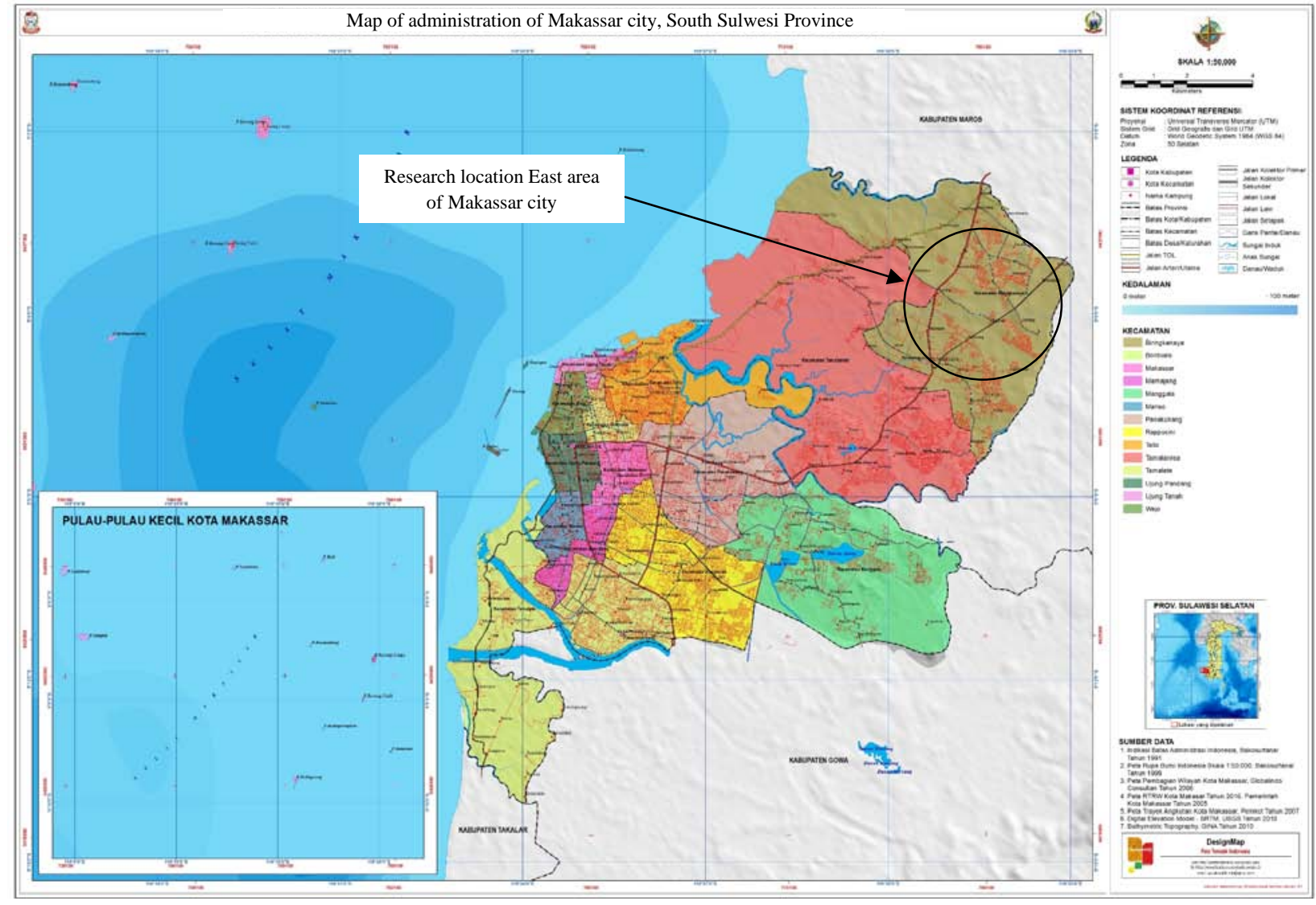

Fig. 1: Map location research: government of Makassar, South Sulawesi province 
Primary data are obtained directly by soil testing in the laboratory and field testing. The primary data as follows:

- $\quad$ Classify of soil test data

- $\quad$ Permeability test data

- Situ observations infiltration data

Based on the objectives in this study, so, it should be performed a qualitative analysis to identify the type of soil in the research, as follows.

Analysis of soil: The type of soil analysis is conducted in Soil Mechanics Laboratory, Department of Civil Engineering, Polytechnic of Ujung Pandang with directly testing method.

Classifying soil: There are two classify systems freqently used, namely USCS (Unified Soil Classification System) and AASTHO (American Association of State Higway and Transportation Official). These systems use the properties of plasticity index. The soil classification of system of unified originally introduced by Casagrande, 1942 (Joseph, 1986).

Permeability: In calculating, the movement of water through the soil in the saturated condition known as Darcy's law which is used in calculating permeability. Darcy's law is a measurement of water flow in saturated soil and formulated as follows (Siregar, 2013): permeability in the laboratory used two methods to calculate.

Constan-head permeability test: Constan-head permeability test remain to be conducted if the experiment that has much water can seep into the soil samples in not long time, then this experiment can be performed by using the following equation:

$$
\mathrm{k}=\frac{\mathrm{Q} \times \mathrm{L}}{\mathrm{A} \times \mathrm{h} \times \mathrm{t}}
$$

Where:

$\mathrm{k}$ : Coefficient of permeability $\left(\mathrm{cm} \mathrm{sec}^{-1}\right)$

$\mathrm{Q}$ : Collected volume of water $\left(\mathrm{cm}^{3}\right)$

$\mathrm{L}$ : Length of soil coloumn (cm)

$\mathrm{h}$ : Head difference $(\mathrm{cm})$

A : Area of sample $\left(\mathrm{cm}^{2}\right)$

$\mathrm{T}$ : Time required to get volume (sec)

Falling head permeability test: Falling head permeability test conducted in which this experiment water seeping into the soil samples is very small, so, this experiment can be performed using the following Eq. 2:

$$
\mathrm{k}=2,303\left(\frac{\mathrm{aL}}{\mathrm{At}}\right) \log \left(\frac{\mathrm{hi}}{\mathrm{hf}}\right)
$$

Where:

$\mathrm{k}$ : Coefficient of permeability $\left(\mathrm{cm} \mathrm{sec}^{-1}\right)$

a : Area of the burette $\left(\mathrm{cm}^{2}\right)$

1 : Lenght of soil coloumn $(\mathrm{cm})$

$A_{t}$ : Area of soil coloumn $\left(\mathrm{cm}^{2}\right)$

$\mathrm{h}_{\mathrm{i}}$ : Initial height of water $(\mathrm{cm})$

Analysis of rainfall, rainfall intensity and runoff discharge

Rainfall: The amount of rainfall on the earth's surface is expressed in water depths (mm) which considered to be distributed even across the catchment area. Rainfall intensity is the amount of rainfall in a unit of time, usually expressed in $\mathrm{mm} / \mathrm{h}, \mathrm{mm} / \mathrm{day}$, $\mathrm{mm} /$ week, $\mathrm{mm} / \mathrm{month}$, $\mathrm{mm} /$ year and so on which successively often called in rain hourly, daily, weekly, monthly, yearly, etc., that are commonly captured on a rain stations but the a rain station only give a depth of rain in that place where the station is located, so, the rain on the area of the station to be estimated from the measurement point. If an area more than one measurement station placed scatterely, rain recorded at each station would not be the same (Bambang, 2008).

In the preparation of a draft water use and flood control, rainfall required the average rainfall across the concerning region and not rainfall at certain points. Rainfall is called rainfall areas estimated from several observation rainfall points. There are a few technique calculations of rainfall the area of observation at some points, the average algebraic methods, Thiessen polygon method and Isohyets method.

However, this study is for regional distribution of precipitation, using average arithmetic method. This method is the simplest at the calculation of regional rainfall as well as it is based on the assumption that all of a pluviometer has similar effects. This method is suitable for the area with a flat topography, a pluviometer tool is uniformly dispersed and the individual cost of rainfall is not too far from the average cost. Rain area is obtained by Eq. 3, the following:

$$
\mathrm{P}=\frac{\mathrm{p}_{1}+\mathrm{p}_{2}+\mathrm{p}_{3} \ldots+\mathrm{p}_{\mathrm{n}}}{\mathrm{n}}
$$

Where:

$\mathrm{P} \quad$ : Rainfall precipitation of current area

$\mathrm{P}_{1}, \mathrm{P}_{2}, \mathrm{P}_{3}$ : Rainfall precipitation of measurement station $\mathrm{n} \quad$ : Amount of rainfall measurement station

Rainfall intensity: Rainfall intensity is a rain per unit of time. General nature of the rain is the shorter rainy occurred, the higher return period occurred. Relation intensity between long rain and rain usually expressed 
with Intensity-Duration-Frequency (IDF) (Suripin, 2004). Analysis curve Intensitas Duration Frequency (IDF) by Mononobe method, conducted to estimate the peak discharge in a small catchment area such as urban planning of drainage systems, culverts and bridges. In the small catchment area, heavy rain with short duration that is fallen in various points over the entire catchment can be concentrated on the control points of interest in the same time which can generate peak flow.

The decline in IDF curves can be conducted if rainfall data is available, in order to obtain the rain with a short duration $(5,10,15, \ldots, \mathrm{min})$. If there is only daily rainfall data, Mononobe proposes the following equation to decline the IDF curve (Bambang, 2008):

$$
I_{t}=\frac{R_{24}}{24}\left(\frac{24}{t}\right)^{\frac{2}{2}}
$$

Where:

$\mathrm{I}_{\mathrm{t}} \quad$ : Rainfall intensity $(\mathrm{mm} / \mathrm{h})$

$\mathrm{t} \quad$ : Rainfall period (h)

$\mathrm{R}_{24}$ : Maximum rainfall in $24 \mathrm{~h}(\mathrm{~mm})$

Runoff discharge: Runoff is part of the rainfall flows over the surface of the soil to the river, lake and ocean. In estimating the flow rate based on the rainfall, data can be used in rational method with the following equation (Sanitya et al., 2015):

$$
\mathrm{Q}=0.00278 \times \mathrm{CIA}
$$

Where:

$$
\begin{array}{ll}
\mathrm{Q} & : \text { Water discharge }\left(\mathrm{m}^{3} \mathrm{sec}^{-1}\right) \\
\mathrm{I} & : \text { Rainfall intensity }\left(\mathrm{mm} \mathrm{h}^{-1}\right) \\
\mathrm{A} & : \text { Area }\left(\mathrm{km}^{2}\right) \\
\mathrm{C} & : \text { Runoff coefficient } \\
0.00278: & \text { A coefficient converted in } \mathrm{m}^{3} \mathrm{sec}^{-1}
\end{array}
$$

If the watershed consists of a wide variety of land use with different surface flow coefficients, the using runoff Coefficient (C) is the runoff coefficient that can be calculated using Eq. 6 or using Table 1, as follows:

$$
C=\frac{\sum_{\mathrm{i}=1}^{\mathrm{n}} \mathrm{c}_{\mathrm{i}}, \mathrm{A}_{\mathrm{i}}}{\sum_{\mathrm{i}=1}^{\mathrm{n}} \mathrm{A}_{\mathrm{i}}}
$$

Requirement number of biopore infiltration holes: The number of holes that need to be made can be calculated using the following equation:

LRB $=\frac{\text { Rainfall intensity }\left(\mathrm{mm} \mathrm{h}^{-1}\right) \times \text { Impermeablearea No. of } \mathrm{m}^{2}}{\text { Rate water filtration per hole }\left(\mathrm{L} \mathrm{h}^{-1}\right)}$
Table 1: Runoff coefficient C

\begin{tabular}{ll}
\hline Land use & C \\
\hline Lawns (\%) & $0.05-0.10$ \\
Sand soil, flat, 2 & $0.10-0.15$ \\
Sand soil, average, 2-7 & $0.15-0.20$ \\
Sand soil, steep, 7 & $0.13-0.17$ \\
Heavy soil, flat, 2 & $0.18-0.22$ \\
Heavy soil, average, 2-7 & $0.25-0.35$ \\
Heavy soil, steep, 7 & \\
Business & $0.75-0.95$ \\
Downtown areas & $0.50-0.70$ \\
Neigborhood areas & \\
Residental & $0.30-0.50$ \\
Singel family areas & $0.40-0.60$ \\
Multi units, detached & $0.60-0.75$ \\
Multi units, attached & $0.25-0.40$ \\
Suburban & $0.50-0.70$ \\
Neighborhood areas & \\
Industrial & $0.50-0.80$ \\
Light areas & $0.60-0.90$ \\
Heavy areas & $0.10-0.25$ \\
Park, cemeteries & $0.20-0.35$ \\
Play grounds & $0.20-0.40$ \\
Railroad yard areas & $0.10-0.30$ \\
Unimproved areas & \\
Streets & $0.75-0.95$ \\
Asphaltic & $0.80-0.95$ \\
Concrete & $0.70-0.85$ \\
Brick & $0.75-0.95$ \\
Roofs &
\end{tabular}

MapInfo: MapInfo is processing spatial data software widely used in the analysis of geographic information system. This software has the ability such as other processing spatial data such as the ArcInfo and ArcView. MapInfo is processing a spatial data software integrated with the table data. With MapInfo, the operator can create, display and change into the spatial data or map. Sources of data in GIS can be obtained by digitizing analogue maps, survey, aerial photographs, satellite imagery and results of scanning data. Therefore, It is necessary for the processing transformation data of converting analog data into digital data, called the map registration. Map ragistration is processing transformation data in mathematics incorporated into the coordinate system into the other coordinate, so, many layers of data can be overlaid on geographic analysis which is valid.

Capability of MapInfo: MapInfo has several characteristics such as easy to use, relatively cheap cost, interactive viewing, friendly user and can be combined by using a scripting language owned. In addition, the structural support data for all platforms, featuring raster as well as vector graphics for the background that can be integrated with the database.

\section{RESULTS AND DISCUSSION}

Laboratory analysis: This experiment is classified by the soil conducted in the Laboratory of Soil Mechanics Civil Engineering, Department of the Polytechnic Ujung Pandang using USCS method. 
J. Eng. Applied Sci., 15 (2): 341-349, 2020

Table 2: Soil classification I

\begin{tabular}{llll}
\hline & Flamboyan NTI Street RW 23 in Tamalanrea \\
Sample source & Test of type & Units & Values \\
\hline Atterberg & LL & & 66.467 \\
& PL & & 35.524 \\
\multirow{5}{*}{ Filtration } & IP & $\%$ & 30.942 \\
& \#3/4" & $\%$ & 3.112 \\
& No. 4 & $\%$ & 3.874 \\
& No. 10 & $\%$ & 6.948 \\
& No. 40 & $\%$ & 10.730 \\
& No. 200 & $\%$ & 7.563 \\
Permeability & Pan & $\%$ & 67.773 \\
& m sec & & $5.42517 \mathrm{E}-08$ \\
\hline
\end{tabular}

Table 3: Soil classification II

\begin{tabular}{llll}
\hline \multirow{3}{*}{ Sample source } & \multicolumn{2}{l}{ Keindahan BTP Street Blok Aa in Tamalanrea } \\
\cline { 2 - 4 } & Test of type & Units & Values \\
\hline Atterberg & LL & & Non Plastis \\
& PL & & \\
Filtration & IP & $\%$ & 0.353 \\
& $\# 3 / 4 ”$ & $\%$ & 4.925 \\
& No.4 & $\%$ & 4.837 \\
& No. 10 & $\%$ & 24.449 \\
& No. 40 & $\%$ & 28.838 \\
& No. 200 & $\%$ & 36.597 \\
& Pan & & $1.36064 \mathrm{E}-06$ \\
\hline
\end{tabular}

Table 4: Soil classification III

Kampung Baru PK 12 in Tamalanrea

\begin{tabular}{llll} 
& & & \\
Sample source & Test of type & Units & Values \\
\hline Atterberg & LL & & 73.833 \\
& PL & & 51.772 \\
\multirow{5}{*}{ Filtration } & IP & $\%$ & 22.062 \\
& $\# 3 / 4 "$ & $\%$ & 0.890 \\
& No. 4 & $\%$ & 0.264 \\
& No. 10 & $\%$ & 0.337 \\
& No. 40 & $\%$ & 1.002 \\
Permeability & No. 200 & $\%$ & 6.422 \\
& Pan & $\%$ & 91.085 \\
& $\mathrm{~m} \mathrm{sec}^{-1}$ & & $6.17957 \mathrm{E}-10$ \\
\hline
\end{tabular}

Location I: Type of soil test USCS: Clay inorganic Higth plasticity $(\mathrm{CH})$ (Table 2).

Location II: Type of soil test USCS: Sand Clay (SC) (Table 3).

Location III: Type of soil test USCS: Clay Organic Higth plasticity $(\mathrm{OH})$ (Table 4).

Location IV: Type of soil test USCS: silt inorganic low plasticity (ML) (Table 5).

Location V: Type of soil test USCS: Clay Hight plasticity (CH) (Table 6).

Location VI: Type of soil test USCS: Clay Hight plasticity (CH) (Table 7).
Table 5: Soil classification IV

\begin{tabular}{|c|c|c|c|}
\hline \multirow[b]{2}{*}{ Sample source } & \multicolumn{3}{|c|}{ Berua RT 03 RW 06, in Paccerakkang } \\
\hline & Test of type & Units & Values \\
\hline \multirow[t]{3}{*}{ Atterberg } & $\mathrm{LL}$ & & 47.000 \\
\hline & PL & & 31.657 \\
\hline & IP & & 15.343 \\
\hline \multirow[t]{6}{*}{ Filtration } & \#3/4” & $\%$ & 0.000 \\
\hline & No. 4 & $\%$ & 4.421 \\
\hline & No. 10 & $\%$ & 4.724 \\
\hline & No. 40 & $\%$ & 19.012 \\
\hline & No. 200 & $\%$ & 19.689 \\
\hline & Pan & $\%$ & 52.154 \\
\hline Permeability & $\mathrm{m} \mathrm{sec}^{-1}$ & & 2.42655E-07 \\
\hline
\end{tabular}

Table 6: Soil classification V

\begin{tabular}{|c|c|c|c|}
\hline \multirow[b]{2}{*}{ Sample source } & \multicolumn{3}{|c|}{ RW 07 Mangga Tiga in Paccerakkang } \\
\hline & Test of type & Units & Values \\
\hline \multirow[t]{3}{*}{ Atterberg } & $\overline{L L}$ & & 61.167 \\
\hline & PL & & 31.723 \\
\hline & IP & & 29.443 \\
\hline \multicolumn{4}{|l|}{ Filtration } \\
\hline & $\# 3 / 4 ”$ & $\%$ & - \\
\hline & No. 4 & $\%$ & 2.387 \\
\hline & No. 10 & $\%$ & 2.723 \\
\hline & No. 40 & $\%$ & 5.903 \\
\hline & No. 200 & $\%$ & 13.677 \\
\hline & Pan & $\%$ & 75.310 \\
\hline Permeability & $\mathrm{m} \mathrm{sec}^{-1}$ & & $6.12032 \mathrm{E}-08$ \\
\hline
\end{tabular}

Table 7: Soil classification VI

\begin{tabular}{llll}
\hline & RW 16 BTP Blok Ae in Paccerakkang \\
Sample source & Test of type & Units & Values \\
\hline Atterberg & LL & & 65.250 \\
& PL & & 31.094 \\
Filtration & IP & $\%$ & 34.156 \\
& \#3/4” & $\%$ & 0.000 \\
& No. 4 & $\%$ & 0.382 \\
& No. 10 & $\%$ & 1.472 \\
& No. 40 & $\%$ & 3.527 \\
& No. 200 & $\%$ & 8.765 \\
Permeability & Pan & & 85.853 \\
\hline
\end{tabular}

Hydrology analysis: Rainfall data used in hydrological analysis in this study was obtained by Regional Agencies of Pompengan Jeneberang river and Meteorology, Cimatology and Geophysics Agencies (MCGA) about four rainfall stations is Hasanudin station $\left(05^{\circ} 04^{\prime} 00^{\prime}\right.$ ' LS, $\left.119^{\circ} 33^{\prime} 00^{\prime} \mathrm{BT}\right)$, Paotere station $\left(05^{\circ} 06^{\prime} 49.5^{\prime}\right.$ 'LS, $\left.119^{\circ} 25^{\prime} 11.4^{\prime \prime} \mathrm{BT}\right)$, Panakukang station (0508'59.4”LS, $\left.119^{\circ} 26^{\prime} 13.9^{\prime \prime} \mathrm{BT}\right)$, Biring Romang station (0510’32.7” LS, $119^{\circ} 28^{\prime} 45.5^{\prime \prime} \mathrm{BT}$ ), rainfall data used in this study is daily rainfall data in the last 10 years from the period 2006-2015 (Table 8 and 9).

Regional frequency analysis: This analysis uses arithmetic algebraic method, for rain the area is obtained by Eq. 3 as shown in Table 10. 
Table 8: Total annual daily rainfall Total annual daily rainfall (mm)

\begin{tabular}{llccc} 
& & & \\
Years & Paotere & Hasanudin & Biring romang & Panakukang \\
\hline 2006 & 3,421 & 3,221 & 1,546 & 2,534 \\
2007 & 3,118 & 2,881 & 1,986 & 2,513 \\
2008 & 3,579 & 3,443 & 2,811 & 3,201 \\
2009 & 3,314 & 2,828 & 2,351 & 2,520 \\
2010 & 4,619 & 3,841 & 3,293 & 3,716 \\
2011 & 3,175 & 3,531 & 3,358 & 3,467 \\
2012 & 2,818 & 2,731 & 3,101 & 2,591 \\
2013 & 7,797 & 3,874 & 3,442 & 3,769 \\
2014 & 3,095 & 2,547 & 2,953 & 2,744 \\
2015 & 3,747 & 2,657 & 3,274 & 2,840 \\
\hline
\end{tabular}

Table 9: Annual maximum daily rainfall

\begin{tabular}{llccc}
\hline & \multicolumn{4}{l}{ Annual maximum daily rainfall $(\mathrm{mm})$} \\
Years & Paotere & Hasanudin & Biring romang & Panakukang \\
\hline 2006 & 196 & 139 & 178 & 181 \\
2007 & 204 & 129 & 121 & 113 \\
2008 & 139 & 157 & 200 & 91 \\
2009 & 134 & 128 & 146 & 200 \\
2010 & 180 & 106 & 109 & 99 \\
2011 & 122 & 129 & 180 & 217 \\
2012 & 141 & 103 & 97 & 115 \\
2013 & 121 & 148 & 189 & 193 \\
2014 & 138 & 123 & 138 & 115 \\
2015 & 131 & 134 & 136 & 139 \\
\hline
\end{tabular}

Table 10: Rain area

\begin{tabular}{|c|c|c|}
\hline Years & Average rainfall (mm) & Average maximum rainfall (mm) \\
\hline 2006 & 2,681 & 174 \\
\hline 2007 & 2,625 & 142 \\
\hline 2008 & 3,259 & 147 \\
\hline 2009 & 2,753 & 152 \\
\hline 2010 & 3,867 & 124 \\
\hline 2011 & 3,383 & 162 \\
\hline 2012 & 2,810 & 114 \\
\hline 2013 & 4,721 & 163 \\
\hline 2014 & 2,835 & 129 \\
\hline 2015 & 3,130 & 135 \\
\hline Average & $3,206.175$ & \\
\hline
\end{tabular}

Analysis of rainfall intensity: Hourly intensity maximum rainfall can be calculated using the equation Mononobe 4, as shown in Table 11:

$$
\begin{aligned}
\mathrm{I}=\frac{\mathrm{R}_{24}}{24}\left(\frac{24}{\mathrm{t}}\right)^{2 / 2} & =\frac{143.975}{24} \times\left(\frac{24}{0.0833}\right)^{2 / 2}=261.620 \mathrm{~mm} \mathrm{~h}^{-1} \\
\mathrm{~T} & =5 \mathrm{~min}=5 / 60=0.0833 \mathrm{~h}
\end{aligned}
$$

Rainfall-runoff analysis: The calculation of runoff duration and return period can be used is in return period rainfall data about 10 years, according to Sanitya et al. (2015) which states that for this type of building water as the drainage channel in the field/residential used the flood (years) between 5 and 10 years (Table 12). Runoff can be calculated in using the Rational method as shown in Eq. 5. For the calculation results can be seen in Table 13:

Built coefficient region analysis: Built coefficient region analysis can be calculated by the ratio between the built region and the overall area that can be seen in Table 14 .
Table 11: Rainfall intensity

\begin{tabular}{llll}
\hline & \multicolumn{2}{l}{ Rainfall intensity $\left(\mathrm{mm} \mathrm{h}^{-1}\right)$ based return period } \\
\cline { 2 - 2 } time $(\mathrm{min})$ & $\mathrm{I}_{2}$ & $\mathrm{I}_{5}$ & $\mathrm{I}_{10}$ \\
\hline 5 & 261.620 & 290.688 & 305.914 \\
10 & 164.810 & 183.122 & 192.714 \\
$\ldots$ & $\ldots$ & $\ldots$ & $\ldots$ \\
110 & 33.321 & 37.024 & 38.963 \\
120 & 31.443 & 34.937 & 36.767 \\
130 & 29.810 & 33.122 & 34.856 \\
$\ldots$ & $\ldots$ & $\ldots$ & $\ldots$ \\
275 & 18.090 & 20.099 & 21.152 \\
280 & 17.874 & 19.859 & 20.900 \\
285 & 17.664 & 19.627 & 20.655 \\
$\ldots$ & $\ldots$ & $\ldots$ & $\ldots$ \\
355 & 15.258 & 16.953 & 17.841 \\
360 & 15.116 & 16.796 & 17.676 \\
\hline
\end{tabular}

\begin{tabular}{|c|c|c|c|}
\hline Location & $\begin{array}{l}\text { Catchment } \\
\text { area }\left(\mathrm{km}^{2}\right)\end{array}$ & $\begin{array}{l}\text { Runoff } \\
\text { coefficient }\end{array}$ & Reason in using $\mathrm{C}$ \\
\hline Tamalanrea & 3.3605049 & 0.7 & $\begin{array}{l}\text { For residental using } \mathrm{C}=0.60 \\
\text { with considering differences } \\
\text { type house and for street } \\
\text { type using } \mathrm{C}=0.80 \text { with } \\
\text { considering street type on } \\
\text { location observation }\end{array}$ \\
\hline Paccerakkang & 2.1080823 & 0.7 & $\begin{array}{l}\text { For residental using } \mathrm{C}=0.60 \\
\text { with considering differences } \\
\text { type house and for street } \\
\text { type using } \mathrm{C}=0.80 \text { with } \\
\text { considering street type on } \\
\text { location observation }\end{array}$ \\
\hline
\end{tabular}

Table 12: Runoff coefficient

\begin{tabular}{|c|c|c|c|}
\hline \multirow[b]{3}{*}{ Location } & \multicolumn{3}{|c|}{ Q runoff $\left(\mathrm{m}^{3} \mathrm{sec}^{-1}\right)$} \\
\hline & \multicolumn{3}{|c|}{ Return period } \\
\hline & 2 & 5 & 10 \\
\hline Tamalanrea & 0.206 & 0.228 & 0.240 \\
\hline Paccerakkang & 0.129 & 0.143 & 0.151 \\
\hline
\end{tabular}

Table 13: Runoff

Table 14: Built coefficient region analysis

\begin{tabular}{llll}
\hline Location & Built region & $\begin{array}{l}\text { Total area } \\
\text { area }\left(\mathrm{m}^{2}\right)\end{array}$ & $\begin{array}{l}\text { Built coefficient } \\
\left(\mathrm{m}^{2}\right) \text { region }(\%)\end{array}$ \\
\hline Tamalanrea & 971.776 & $1,441.057$ & 67.435 \\
Paccerakkang & $2,012.897$ & $2,623.343$ & 76.730 \\
\hline
\end{tabular}

Table 15: Analysis of location is suitable to be applied biopore

\begin{tabular}{|c|c|c|c|c|}
\hline Location & Soil type & $\begin{array}{l}\text { Rain } \\
\text { fall }\end{array}$ & $\begin{array}{l}\text { Built } \\
\text { coefficient } \\
\text { region }\end{array}$ & Score \\
\hline I & Middle permeability & High & Less & 45/less suitable \\
\hline II & Middle permeability & High & Less & 45/less suitable \\
\hline III & Low permeability & High & Less & 40/less suitable \\
\hline IV & Middle permeability & High & High & 55/Suitable \\
\hline $\mathrm{V}$ & Low permeability & High & High & 50/Suitable \\
\hline$\underline{\mathrm{VI}}$ & Low permeability & High & High & 50/Suitable \\
\hline
\end{tabular}
infiltration hole

Weighting applied suitable location biopore analysis: The results of the analysis of suitable locations biopore infiltration hole applied research sites can be seen in Table 15. From calcualting weight, it is known as the interval with three classes of land suitable application of biopore infiltration hole contained as follows: 
- Score $\geq 50$ is suitable for applying in biopore infiltration hole

- Interval score 35-45 is less suitable for applying on biopore infiltration hole

- Interval skor 10-30 is not suitable for applying biopore infiltration hole (Anonymous, 1991)

Need analysis of biopore infiltration hole: By using $Q$ runoff return period rainfall of 10 years and a duration of $2 \mathrm{~h}$, it can calcualate the required amount biopori holes to prevent the inundation, the return period rainfall of 10 years and a duration of $2 \mathrm{~h}$ is used for data at this point is a standard that is most adequate to cope with inundatio in the area of research, Sanitya et al. (2015) which states that for types of buildings such as water drainage channels in the field/residential use flood return period (years) between 5 and 100 years.

From the identification of suitable for applying biopore infiltration hole locations, there are three locations including locations could be applied for biopore namely the area IV, area V and VI location, so, the calculation of the amount of absorption holes biopori can be made on the site with the following equation:

$$
\begin{aligned}
& \text { Number LRB }=\frac{\mathrm{R} \text { Runoff } \mathrm{f}}{\mathrm{Q} \text { Infiltration }} \\
& \text { Number LRB }=\frac{0.151}{1,7867 \mathrm{E}-06}
\end{aligned}
$$

Based on the calculation needs, biopore infiltration hole obtained total biopore infiltration hole of each location that have been analyzed suitability of the location, so, there are three locations which are suitable to be applied biopore infiltration hole that the IV site need about 84.417 biopore infiltration hole on location $\mathrm{V}$ takes 6.894 holes biopori infiltration and the VI takes 6,644 1 biopore infiltration hole locations.

\section{Mapping in GIS applications using MapInfo Software:} Mapping location which is approriate to be applied for biopre infiltration holes by using MapInfo 11.0 Software, a source map that maps the Earth Bakosurtanal in 1991 and satellite imagery. The use of satellite imagery aims to make it easier to register on MapInfo with helping of GIS applications Elshayal first Arabian Software that are connected directly to the Google Earth.

Depiction of map locations location Biopre Infiltration hole can be conducted by using some applications of geographic information systems software MapInfo and Elshayal first Arabian GIS Softwere. One datum is obtained either for primary or secondary data. We start drawing the map location of biopore infiltration hole. Image results obtained from several layers, overlay either layer boundaries or layer of the point data of coordinates biopore infiltration holes location.

In Fig. 2, the results of mapping and tabular data as location information are appropriate and not appropriate biopori hole infiltration. This is an arrangement of

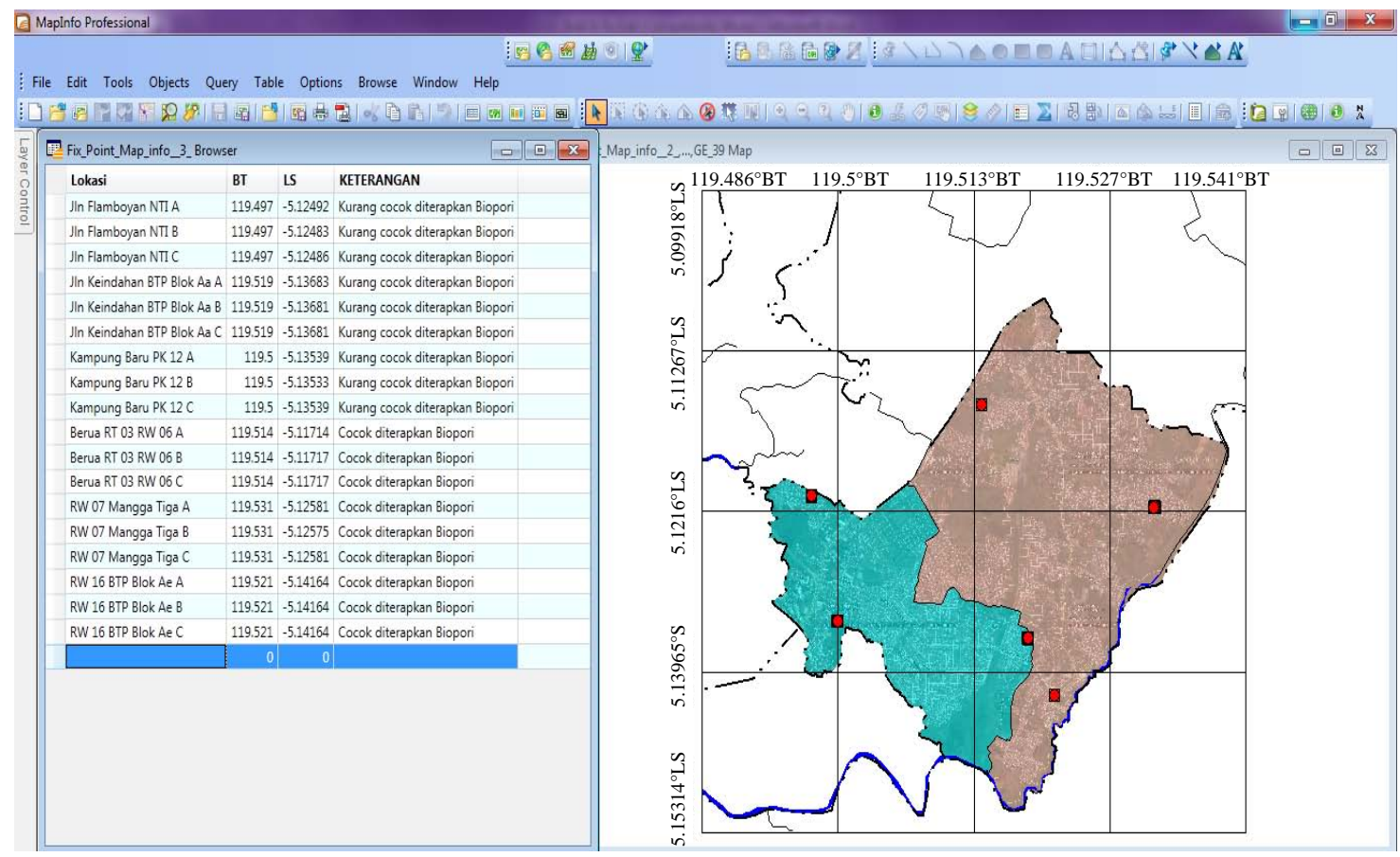

Fig. 2: Display maps and tabular data on MapInfo Software 


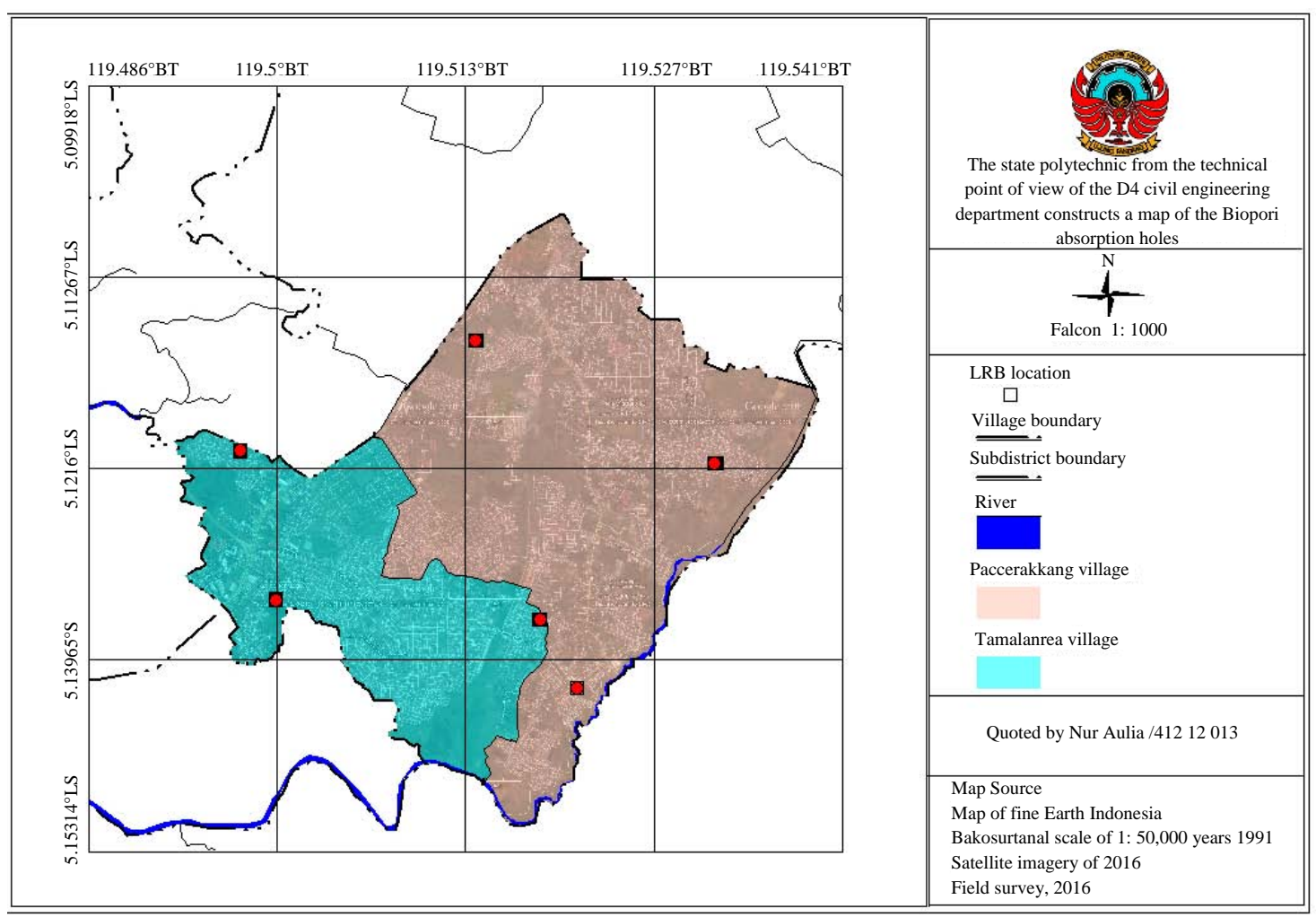

Fig. 3: Ruslt of mapping on MapInfo Software

appropriate technologies that are environmentally friendly application of Geographical Information Systems (GIS), particularly MapInfo application that describes the suitable locations for the application of this technology for coordinates research.

Based on the results of land testing classification conducted in Soil Mechanic Laboratory of Civil Engineering Department of the Polytechnic Ujung Pandang using USCS method, as shown from Table 2-7, obtained by soil type at the location I: Clay Inorganic Hight plasticity (CH), lokasi II: Sand Clay (SC), lokasi III: Clay Organic Hight plasticity (OH), lokasi IV: Clay Organic Hight plasticity $(\mathrm{OH})$, lokasi V: Clay Hight plasticity $(\mathrm{CH})$ and lokasi VI: Clay Hight plasticity $(\mathrm{CH})$. It demonstrates that the study site had coefficient permeability (k) is low to moderate. For the analysis of the maximum average rainfall based on Hasanuddin station, Paotere station, station and Panakkukang, Biring Romang station as shown from Table 8-10. It shows that the study site has high rainfall. Mean while, the result of daily rainfall intensity by using Monobe method is obtained as can be seen in Table 11. It shows an increasing in the intensity of rainfall every year where the the highest rainfall intensity occured in the period $\left(\mathrm{T}_{10}\right)$, about $305.914 \mathrm{~mm} \mathrm{~h}^{-1}$ and decreased in rainfall intensity with rainfall duration $2 \mathrm{~h}$ for $36.767 \mathrm{~mm} \mathrm{~h}^{-1}$. In runoff by
Eq. 5 as shown in Table 13 was obtained at each study site which is at the village Tamalanrea about $0.240 \mathrm{~m}^{3}$ $\mathrm{sec}^{-1}$ for period of re- $\mathrm{T}_{10}$ and village Paccerakang about $0.151 \mathrm{~m} \mathrm{sec}^{-1}$ for period of re- $\mathrm{T}_{10}$. It shows that the Tamalanrea has higher rainfall compared to paccerakang. The results of built coefficient region based on the comparison between the building area and the total area, as shown in Table 14. This shows that the tamalanrea has a good catchment flood when comparing to paccerakang. The results of the analysis of suitable locations applied Infiltration hole on the location of the study as shown in Table 15, shows that the location is suitable to be applied biopore infiltration biopori hole, namely the village Tamalanrea comprising three locations, namely locations IV requires 84.417 biopore infiltration biopore hole, on $6.894 \mathrm{~V}$ required biopore infiltration holes location and the VI requires 6.644 biopore absorption holes locations.

\section{CONCLUSION}

From six locations, there are three sites suitable to be applied biopore infiltratiom holes, IV RT 3 RW 6 Berua location, V RW 7 Mangga Tiga and of RW 16 Blok VI Ae paccerakkang BTP location and there are three locations are also included in the category less suitable to be applied biopori infiltration hole that is at location of the 
I RW 23 Flamboyan NTI street, II Keindahan Blok Aa BTP street location and III Kampung Baru PK 12 on the Tamalanrea location. With the amount of biopori infiltration hole needed from each of the research sites that have been analyzed suitability of the location, so, there are three locations are suitable to be applied biopore infiltration hole that the IV site needed about 84.417 biopore infiltration hole on location V requires 6.894 infiltration hole biopore and on VI requires 6.644 biopore infiltration hole locations.

Utilizing Geographic Information System (GIS) software to implement biopore infiltration by mapping suitable location to be applied on biopore infiltration hole and the number of needs in the region.

\section{ACKNOWLEDGEMENTS}

The researcher would like say thanks for, Regional Disaster Management Agencies (RDMA), Meteorology, Climatology and Geophysics Agencies (MCGA), Regional Agencies Pompengan Jeneberang river also Spatial Plan Service Makassar which has provided data in the framework of this reaearch. Similarly, the researcher convey to the Director of State Polytechnic of Ujung Pandang which has provided support, so, this reserach can be implemented as well.

\section{REFERENCES}

Anonymous, 1991. Land capability classification. Faculty of Geography, Gadjah Mada University, Yogyakarta, Indonesia.
Bambang, T., 2008. [Applied Hydrology]. Penerbit Beta Offset, Yogyakarta, Indonesia, (In Indonesian).

Basuki, S.B., 2013. Model of infiltration rain method using absorption biopore hole (LRB) in flood prevention. Civ. Eng. Rides, 18: 1-12.

Indrianawati, S.M., 2013. Preparation for identification data base flood prone areas associated with spatial data infrastructure. Itenas Eng. J., 1: 22-31.

Joseph, B.E., 1986. Properties-Physical Properties and Geotechnical Land. Equinox Publishing, Jakarta, Indonesia,.

Rizki, M., 2014. Application of hole infiltration biopore as an alternative to minimize flood in ciledug indah housing region I. Master Thesis, Esa Unggul University, West Jakarta, Indonesia.

Sanitya, R.S., 2015. Siting and total hole infiltration biopore das cikapundung in region central section. Master Thesis, Program Study of Urban and Regional Planning, Faculty of Engineering, Universitas Islam Bandung, Bandung, Indonesia.

Siregar, N.A., 2013. Study permeability some soil type soil experiments in kwala bekala USU through field test laboratory. J. Food Agric. Eng., 1: 138-143.

Suripin, 2004. Sustainable Urban Drainage Systems. CV Andi Offset, Depok, Indonesia.

Wahyuningtyas, A., 2011. Implementation of strategy infiltration wells as echo drainage technology in Malang (case study: Sub das metro). J. Urban Plann. Reg., 3: 25-31. 